\title{
Erratum to: Association of Environmental Toxic Elements in Biological Samples of Myocardial Infarction Patients at Different Stages
}

Hassan Imran Afridi • Tasneem Gul Kazi • Naveed Kazi • Ghulam Abbas Kandhro • Jameel Ahmed Baig • Mohammad Khan Jamali • Mohammad Balal Arain • Abdul Qadir Shah • Faheem Shah • Sumaira Khan • Nida Fatima Kolachi

\section{Erratum to: Biol Trace Elem Res}

\section{DOI 10.1007/s12011-010-8713-2}

The original version of this article unfortunately contained mistakes.

In Table 2, the units of white blood cell count and platelet count should be $\mathrm{K} / \mathrm{mm}^{3}$, while $\mathrm{M} / \mathrm{mm}^{3}$ for red blood cell count.

The online version of the original article can be found at http://dx.doi.org/10.1007/s12011-010-8713-2.

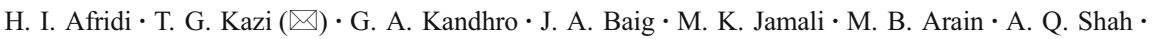
F. Shah $\cdot$ S. Khan $\cdot$ N. F. Kolachi

National Center of Excellence in Analytical Chemistry, University of Sindh, Jamshoro 76080, Pakistan e-mail: tgkazi@yahoo.com 